\title{
Effects of Different Chemical Fertilizers Application Rates and Densities on the Whole Growth Period of Sorghum in Semi-Arid Areas of North China
}

\author{
JINPENG WEI ${ }^{1}$, WENJING SHAO ${ }^{1}$, KEJUN YANG ${ }^{1}$, CHANGJIANG ZHAO ${ }^{1}$, XINYU LIU ${ }^{1}$, \\ WENXU MA ${ }^{1,2}$, GAOBO YU ${ }^{1 *}$, JINGYU XU ${ }^{1,2^{*}}$ \\ ${ }^{1}$ Heilongjiang Bayi Agricultural University, No.5 Xinfeng Road,Daqing, 163319, China \\ ${ }^{2}$ National Coarse Cereals Engineering Research center, Heilongjiang Bayi Agricultural University, No.5 Xinfeng \\ Road,Daqing, 163319, China
}

\begin{abstract}
Sorghum is one of the most important economic crops in the semi-arid areas of northern China. However, its yield is still relatively low, and some factors, such as the amount of different chemical fertilizers application and planting density, limit the increase of yield. In order to study the effect of fertilizer application rate and planting density on the growth and yield of sorghum, Longza 16 was used as test variety material, and the experiment was conducted with the split plot design. The fertilizer application $\left(375 \mathrm{~kg} / \mathrm{hm}^{2}(N: P: K=1: 0.7: 0.4), \quad 375 \mathrm{~kg} / \mathrm{hm}^{2}(N: P: K=1: 0.7: 0.8), \quad 375 \mathrm{~kg} / \mathrm{hm}^{2}\right.$ (N:P:K=1:0.7:1.6), $750 \mathrm{~kg} / \mathrm{hm}^{2}$ (N:P:K=1:0.7:0.8), $\left.750 \mathrm{~kg} / \mathrm{hm}^{2}(N: P: K=1: 0.7: 1.6)\right)$ was designed as main plot and planting density $\left(96000\right.$ plants $/ \mathrm{hm}^{2}, 109000$ plants $/ \mathrm{hm}^{2}, 128000$ plants $/ \mathrm{hm}^{2}, 154000$ plants $/ \mathrm{hm}^{2}$ ) was arranged as subplot. The photosynthetic parameters and yield-related characters were determined during the whole growth period of sorghum. The results showed that the effect of fertilizer application on the yield of sorghum was significant. The yield increased with the increase of fertilizer application, and the yield of $750 \mathrm{~kg} / \mathrm{hm}^{2}(N: P: K=1: 0.7: 1.6)$ was significantly higher than that of other treatments. Different planting densities also had a significant effect on the yield, showing that the yield increased with the increase of density, and the yield was the highest under the density of 154000 plants $/ \mathrm{hm}^{2}$. In addition, the result of composite effect of fertilizer application rate and density showed that the yield of the treatment of $750 \mathrm{~kg} / \mathrm{hm}^{2}(N: P: K=1: 0.7: 1.6)$ and 154000 plants $/ \mathrm{hm}^{2}$ was the highest, which was considered to be more suitable for the production of sorghum in the semi-arid areas of northern China.
\end{abstract}

Keywords: sorghum, chemical fertilizer, density, yield

\section{Introduction}

The natural conditions in the semi-arid areas of northern China are limited for plant growing and yield formation, such as water shortage and strong winds, which seriously affect the normal growth of local crops [1] . Compared with other crops, sorghum is one of the most important economic crops in semi-arid areas because of its high biomass, drought resistance, saline-alkali tolerance and so on [2-3] . In China, sorghum is mostly planted in areas with low soil fertility, because of its high resistance and tolerance. And the lack of planting technical experience also results in reducing the yield of sorghum. Fertilizer application rate and planting density are always important factors affecting crop yield and quality[4-5]. The effect of fertilizer application rate and planting density on crop growth has been confirmed in a lot of crops, indicating that the use of reasonable fertilizer application rate and planting density is very beneficial and important for crop growth [5-7]. Currently, most studies on improving the yield and quality of sorghum are mainly focused on breeding, while some studies on cultivation factors are only aimed at a single factor. As a result, the interaction between fertilizer application rate and density of sorghum is relatively studied insufficiently. It showed that the increase in crop yield is due to reasonable planting density rather than an increase in yield per plant [8]. And the suitable planting density is an important factor affecting the yield of sorghum [9]. It showed that plant height,

\footnotetext{
*email: yugaobo81@163.com
} 
leaf area per plant and dry matter accumulation per plant were significantly different in the late growth stage of feeding sweet sorghum under different fertilizer application rates, and the amount of fertilizer application was the key factor affecting the yield of feeding sweet sorghum [10]. In fact, the improvement of sorghum yield is affected by many factors. Selecting high-yielding varieties combining with suitable fertilizer application rate and density is necessary to obtain super-high yield [11-13]. Therefore, it is of great significance to explore the appropriate amount of fertilizer application and planting density of sorghum, and form a reasonable combination, which could make sorghum grow better and improve its yield and quality.

\section{Materials and methods}

\subsection{Experimentation}

This study was carried out in Daqing City, Heilongjiang Province, China (latitude $45^{\circ} 46^{\prime} \sim 46^{\circ} 55^{\prime}$ $\mathrm{N}$, longitude $124^{\circ} 19^{\prime} \sim 125^{\circ} 12^{\prime} \mathrm{E}$ ). It belongs to the continental monsoon climate of the northern cold temperate zone, with dry and windy spring. The terrain of the test site is flat, with an elevation of 128 $\sim 167 \mathrm{~m}$, an average annual air temperature of $4.6^{\circ} \mathrm{C}$, an active accumulated temperature of more than $2800^{\circ} \mathrm{C}$, an annual average sunshine of $2782.5 \mathrm{~h}$ and a frost-free period of 136 days. The chemical properties of the tested soil were shown in Table 1.

Table1. Characteristic of soil used in this study.

\begin{tabular}{cccccc}
\hline $\begin{array}{c}\text { Soil depth } \\
(\mathbf{c m})\end{array}$ & $\begin{array}{c}\text { Alkaline hydrolysable } \mathbf{N} \\
(\mathbf{m g} / \mathbf{k g})\end{array}$ & $\begin{array}{c}\text { Available } \mathbf{P} \\
(\mathbf{m g} / \mathbf{k g})\end{array}$ & $\begin{array}{c}\text { Available K } \\
(\mathbf{m g} / \mathbf{k g})\end{array}$ & $\begin{array}{c}\text { Organic } \\
\mathbf{m a t t e r}(\mathbf{g} / \mathbf{k g})\end{array}$ & $\mathbf{p H}$ \\
\hline $0-20$ & 91.00 & 17.31 & 62.65 & 16.53 & 7.15 \\
\hline
\end{tabular}

Longza 16 was used as tested variety. Fertilizer application rates $\left(\mathrm{F} 1: 375 \mathrm{~kg} / \mathrm{hm}^{2}(\mathrm{~N}: \mathrm{P}: \mathrm{K}=1: 0.7: 0.4)\right.$, $\mathrm{F} 2: 375 \mathrm{~kg} / \mathrm{hm}^{2}$ (N:P:K=1:0.7:0.8), F3:375kg/hm² (N:P:K=1:0.7:1.6), F4:750kg/hm² (N:P:K=1:0.7:0.8), $\mathrm{F} 5: 750 \mathrm{~kg} / \mathrm{hm}^{2}(\mathrm{~N}: \mathrm{P}: \mathrm{K}=1: 0.7: 1.6)$ ) was designed as main plot and planting density (M1:96000 plants $/ \mathrm{hm}^{2}$, M2:109000 plants $/ \mathrm{hm}^{2}$, M3:128000 plants $/ \mathrm{hm}^{2}$, M4:154000 plants $/ \mathrm{hm}^{2}$ ) was arranged as subplot, which were randomly arranged and repeated three times. The test code is shown in Table 2.

Table 2. The symbol of different treatment for split-plot experiment.

\begin{tabular}{ccc}
\hline Processing & $\begin{array}{c}\text { Fertilizer Application Rates } \\
\left(\mathbf{k g} / \mathbf{h m}^{\mathbf{2}}\right)\end{array}$ & $\begin{array}{c}\text { Planting Density } \\
\left(\mathbf{p l a n t s} / \mathbf{h} \mathbf{m}^{\mathbf{2}}\right)\end{array}$ \\
\hline F1M1 & $375(\mathrm{~N}: \mathrm{P}: \mathrm{K}=1: 0.7: 0.4)(\mathrm{F} 1)$ & $10.9(\mathrm{M} 2)$ \\
\hline F1M2 & & $12.8(\mathrm{M} 3)$ \\
\hline F1M3 & & $15.4(\mathrm{M} 4)$ \\
\hline F1M4 & $9.6(\mathrm{M} 1)$ \\
\hline F2M1 & $375(\mathrm{~N}: \mathrm{P}: \mathrm{K}=1: 0.7: 0.8)(\mathrm{F} 2)$ & $10.9(\mathrm{M} 2)$ \\
\hline F2M2 & & $12.8(\mathrm{M} 3)$ \\
\hline F2M3 & $15.4(\mathrm{M} 4)$ \\
\hline F2M4 & $9.6(\mathrm{M} 1)$ \\
\hline F3M1 & $10.9(\mathrm{M} 2)$ \\
\hline F3M2 & $12.8(\mathrm{M} 3)$ \\
\hline F3M3 & $375(\mathrm{~N}: \mathrm{P}: \mathrm{K}=1: 0.7: 1.6)(\mathrm{F} 3)$ & $15.4(\mathrm{M} 4)$ \\
\hline F3M4 & $9.6(\mathrm{M} 1)$ \\
\hline F4M1 & $10.9(\mathrm{M} 2)$ \\
\hline F4M2 & $12.8(\mathrm{M} 3)$ \\
\hline F4M3 & $15.4(\mathrm{M} 4)$ \\
\hline F4M4 & $9.6(\mathrm{M} 1)$ \\
\hline F5M1 & $10.9(\mathrm{M} 2)$ \\
\hline F5M2 & $12.8(\mathrm{M} 3)$ \\
\hline F5M3 & & $15.4(\mathrm{M} 4)$ \\
\hline F5M4 & & $(\mathrm{N}: \mathrm{P}: \mathrm{K}=1: 0.7: 0.8)(\mathrm{F} 4)$ \\
\hline
\end{tabular}




\subsection{Measurements and Analyses}

The leaf areas of five different plants in the same position were measured at seedling stage, jointing stage, flowering stage, filling stage and mature stage of sorghum, and each treatment was repeated 3 times. Leaf area $=$ length $\times$ width $\times 0.75$ ( 0.75 is the correction coefficient), leaf area index $=$ leaf area per plant $\times$ number of plants per unit land area /unit land area. At seedling stage, jointing stage, heading and flowering stage, filling stage and mature stage of sorghum, the photosynthetic rate was measured by LI- 6400 portable photosynthesis system. The light intensity of artificial light source was $800 \mu \mathrm{mol} \mathrm{m}^{-}$ ${ }^{2} \cdot \mathrm{s}^{-1}$, and each treatment was repeated for three times. The chlorophyll was measured by SPAD-502 Plus chlorophyll meter at seedling stage, jointing stage, heading and flowering stage, filling stage and mature stage of sorghum, and each treatment was repeated for 3 times. After all the panicles were harvested, the grain was threshed and weighed, and the plot yield was calculated, and 10 panicles were randomly selected to measure panicle length, grain number per panicle, 1000-grain weight, panicle weight and grain weight per panicle.

\subsection{Statistical Analysis}

Analysis of Variance (ANOVA) was applied with SPSS 21. The general linear model procedure was used for analysis. Fertilizer application rates and plant density treatment was set as fixed factors, including all interactions. Replicate was considered a random factor. Duncan's multiple range test was used for the difference significance at $\mathrm{P}<0.05$ and Excel was used for statics analysis the figure's preparation.

\section{Results and discussions}

\subsection{Effect of Fertilizer and Density Factors on Photosynthetic Rate of Sorghum}

As shown in Figure 1, the change trend of photosynthetic rate after different fertilizer application rate and planting density was almost the same. From seedling stage to mature stage, photosynthetic rate increased at first and then decreased, and achieved to its peak and were highest in flowering stage than other stages. The photosynthetic rate of Sorghum of Fertilizer Application Rates at F2 was higher than other treatments in Planting Density of M1 from seedling stage to flowering stage. However, the photosynthetic rate of Sorghum of M1F5 was higher than others in the filling stage. The effect of different fertilizer application amount was distinct in different growth period in the same planting density. During the whole growth period, with the same amount of fertilizer application, the change trend of photosynthetic rate in each period was M1> M2> M3> M4. It indicated that the difference of photosynthetic rate was mainly reflected in the effect of density on leaves, while the amount of fertilizer application and fertilizer ratio had little effect on the photosynthetic rate of leaves.

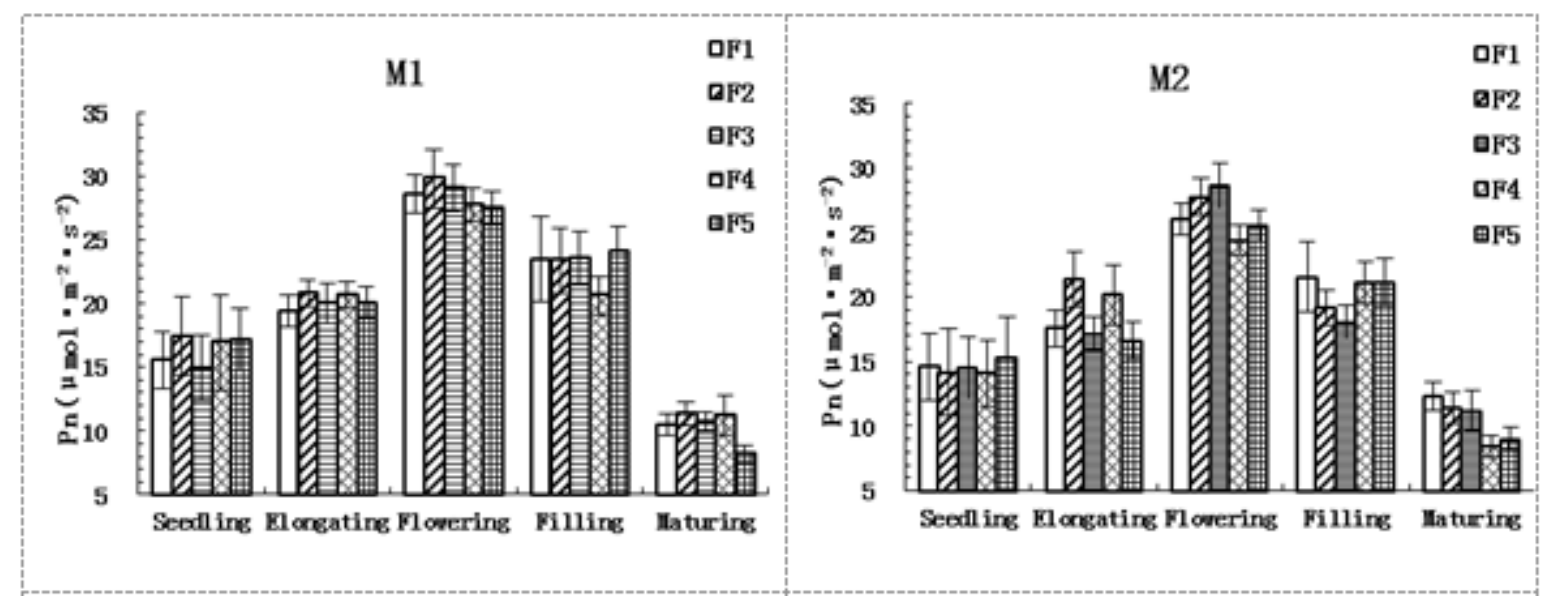




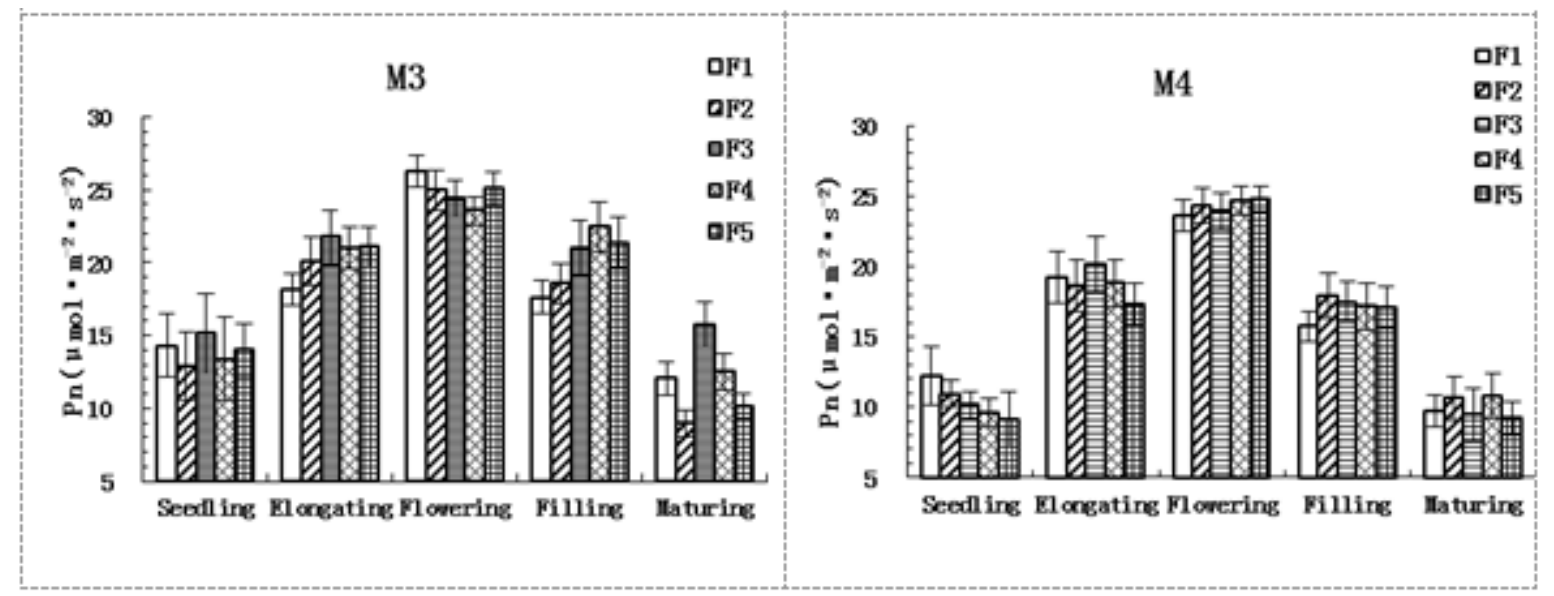

Figure 1. Effects of fertilization and density on photosynthetic rate

\subsection{Effect of Fertilizer and density factors on chlorophyll content of Sorghum}

As shown in Figure 2, during the whole growth period, the chlorophyll content increased at first and then decreased, and the peak appeared at the flowering stage. With the increase of density, the content of chlorophyll decreased in the whole growth period. The content of chlorophyll of sorghum in the same density increased with the increase of fertilizer application. However, under the same amount of fertilizer application, the content of chlorophyll decreased with the increase of density. Under the condition of different fertilizer application rates, the significant differences between F4, F5 and F1, F2, F3 appeared after the booting and flowering stages. With the influence of both fertilizer application rate and density, the chlorophyll content of F4M1 was higher in the later growth stage, which indicated that the function of leaves could remain for a long time relatively under this cultivation condition.

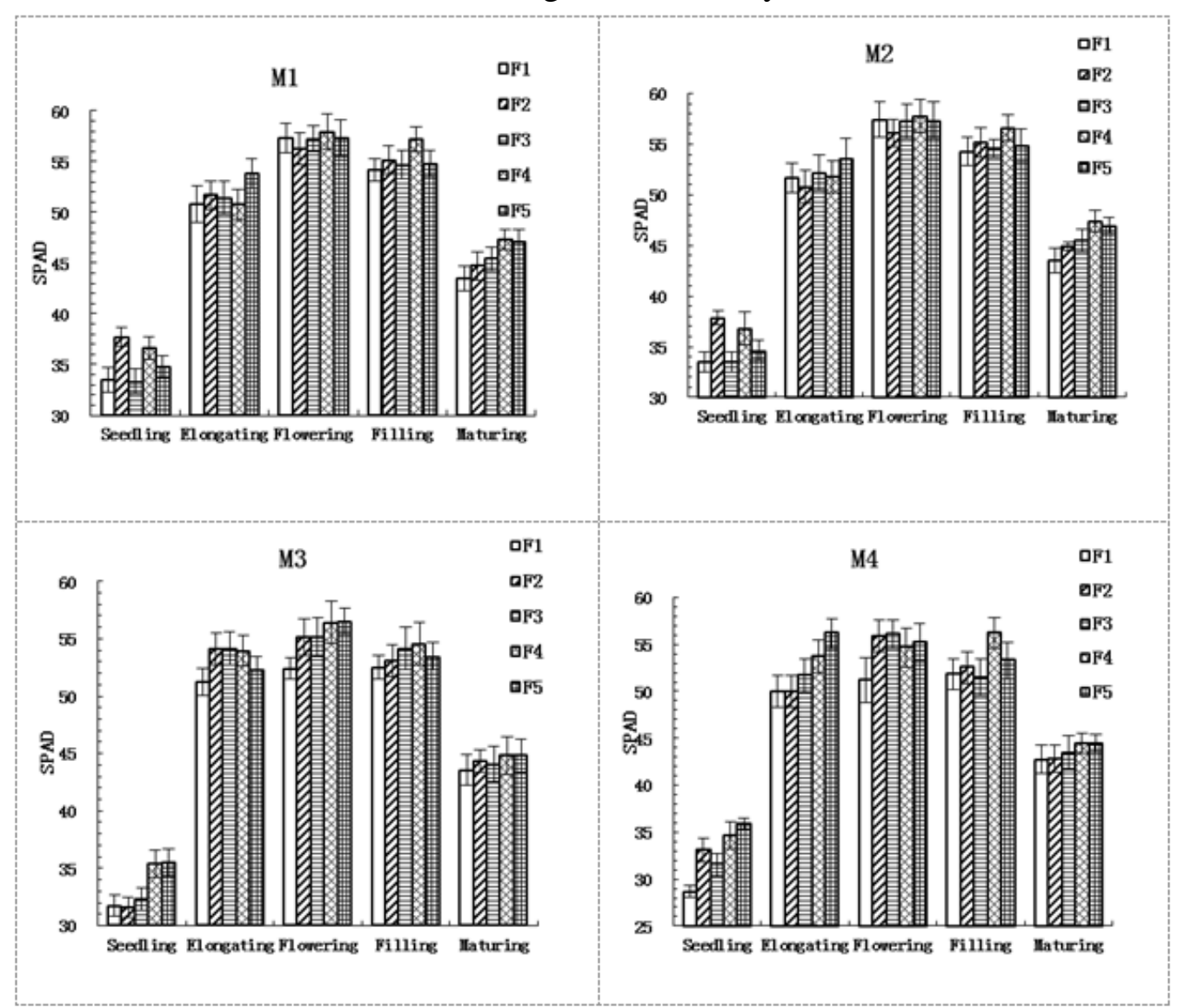

Figure 2. Effects of fertilization and density on chlorophyll content 


\subsection{Effect of Fertilizer and density on Leaf area Index of Sorghum}

Photosynthesis is mainly carried out through plant leaves, and the photosynthesis of plant population is affected by the change of population leaf area index directly. The results showed that the trend of the leaf area index appeared similar with photosynthesis and chlorophyll content of Sorghum. With the growth of plant, the leaves extended gradually, and the leaf area index increased significantly until the flowering stage, and then descended slowly (Figure 3). At the filling and maturing stage, due to the senescence and shedding of the lower leaves of the plant, the leaf area index decreased. Although application with the same amount of fertilizer, the effect of density on the leaf area index of sorghum was significantly different in different growth stages. With the increase of density, the leaf area index increased, and the overall trend was as follows: M4> M3> M2> M1. Under the condition of high density, the leaf area index of F4 and F5 treatments was significantly higher than that of other treatments, which is because the nutrient competition among plants was more fierce in treatments with high density, to ensure the growth and development of plants. However, the lack of nutrient limited the formation of yield under F1, F2 and F3 treatments. As a result, the leaf area index increased with the increase of total fertilizer application.

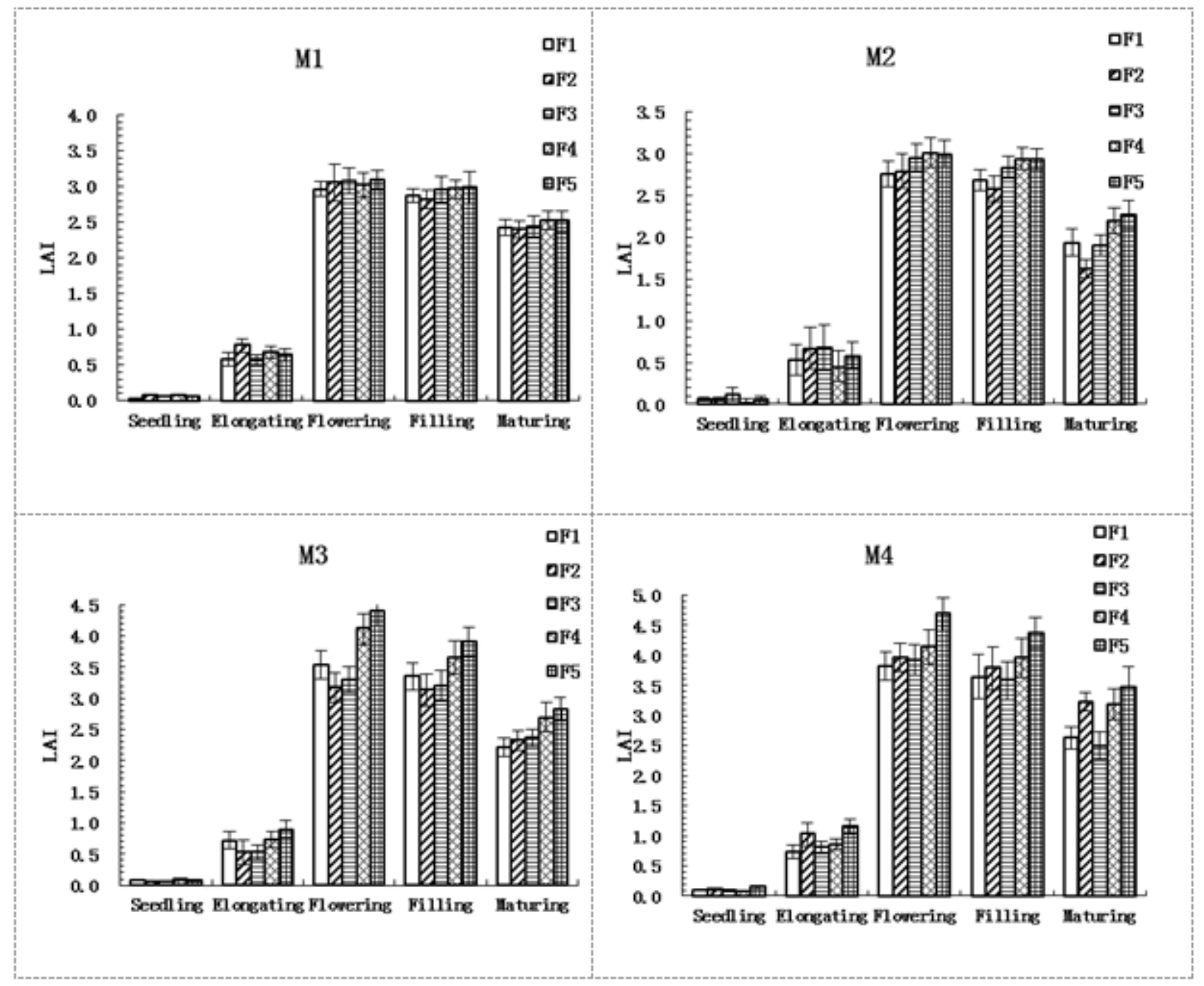

Figure 3. Effects of fertilization and density on leaf area index

\subsection{Effects of Fertilizer and density factors on yield and related characters of Sorghum}

It was shown that effects of different fertilizer application amount and density on the yield of sorghum were significantly different (Table 3). The increasing of density made some plants shaded by other plants, resulting in a lower photosynthetic efficiency, and the grain formation was limited, which finally led to the decrease of yield per plant. Among them, the yield of F5 treatment was significantly 
higher than other fertilizer application treatments. In terms of yield-related traits, the yield advantage of F5 treatment was mainly due to higher 1000-grain weight and grain weight per panicle. The yield increased with the increase of fertilizer application. Under the condition of the same amount of fertilizer F1, F2 and F3, the effect of the proportion of potassium fertilizer on yield was significant by affecting the photosynthetic characteristics and increasing the dry matter accumulation per plant. The yield of M3 and M4 was significantly higher than that of M1 and M2, and the yield of M4 was the highest. With the increase of density, 1000-grain weight, panicle length, grain weight per panicle and panicle weight decreased. Under the condition of density, the correlation order between yield related traits and yield was grain weight per panicle $>$ panicle length $>1000$-grain weight $>$ panicle weight.

Table 3. Effects of Fertilizer Application rate and density on yield and related characters.

\begin{tabular}{|c|c|c|c|c|c|c|}
\hline $\begin{array}{l}\text { Experimental } \\
\text { Factor }\end{array}$ & & $\begin{array}{l}\text { Thousan } \\
\text { d kernel } \\
\text { weight(g } \\
\text { ) }\end{array}$ & $\begin{array}{l}\text { Panicle } \\
\text { length } \\
(\mathrm{cm})\end{array}$ & $\begin{array}{c}\text { Grain } \\
\text { weight } \\
\text { (g) }\end{array}$ & $\begin{array}{c}\text { Spike } \\
\text { weight } \\
\text { (g) }\end{array}$ & $\begin{array}{l}\text { Grain yield } \\
\left(\mathrm{kg} / \mathrm{hm}^{2}\right)\end{array}$ \\
\hline \multirow{5}{*}{$\begin{array}{c}\text { Fertilizer } \\
\text { Application rate }\end{array}$} & F1 & $22.91 \mathrm{~b}$ & $22.68 \mathrm{a}$ & $71.93 \mathrm{a}$ & $90.57 \mathrm{a}$ & $874521 c$ \\
\hline & $\mathrm{F} 2$ & $24.72 \mathrm{a}$ & $21.99 \mathrm{a}$ & $72.19 \mathrm{a}$ & $94.66 \mathrm{a}$ & $8883.46 b c$ \\
\hline & F3 & $24.28 \mathrm{ab}$ & $22.44 a$ & $77.03 \mathrm{a}$ & $95.68 \mathrm{a}$ & $9300.50 \mathrm{ab}$ \\
\hline & $\mathrm{F} 4$ & $23.74 \mathrm{ab}$ & $22.44 a$ & $73.10 \mathrm{a}$ & $90.45 \mathrm{a}$ & 9311.91ab \\
\hline & F5 & $25.07 \mathrm{a}$ & $21.99 \mathrm{a}$ & $76.74 a$ & $98.96 \mathrm{a}$ & $9401.78 \mathrm{a}$ \\
\hline $\begin{array}{l}\text { Correlation } \\
\text { coefficient } \\
\end{array}$ & & 0.6294 & 0.7002 & 0.6442 & 0.5917 & \\
\hline \multirow{4}{*}{ Planting density } & M1 & $25.10 \mathrm{a}$ & $22.71 \mathrm{a}$ & $82.40 \mathrm{a}$ & $109.03 \mathrm{a}$ & $8172.70 \mathrm{c}$ \\
\hline & M2 & $23.77 b$ & $22.27 \mathrm{ab}$ & $70.56 \mathrm{~b}$ & $90.68 \mathrm{~b}$ & $8567.28 \mathrm{c}$ \\
\hline & M3 & $23.87 \mathrm{~b}$ & $22.47 \mathrm{ab}$ & $73.75 b$ & $90.77 b$ & $9573.96 \mathrm{~b}$ \\
\hline & M4 & $23.83 b$ & $21.77 \mathrm{~b}$ & $70.08 \mathrm{~b}$ & $85.76 \mathrm{~b}$ & $10160.37 \mathrm{a}$ \\
\hline $\begin{array}{l}\text { Correlation } \\
\text { coefficient } \\
\end{array}$ & & 0.5827 & 0.5916 & 0.6012 & 0.5397 & \\
\hline \multirow[t]{2}{*}{ Mean square } & $\begin{array}{l}\text { Fertilizer } \\
\text { Application } \\
\text { rate }\end{array}$ & $28.93 *$ & NS & NS & NS & $1114113.30^{* *}$ \\
\hline & $\begin{array}{l}\text { Planting } \\
\text { density }\end{array}$ & NS & $7.99 *$ & $1629.74 *$ & $5250.92^{*}$ & $12456598.57^{* *}$ \\
\hline
\end{tabular}

Note: Same small letters indicate no significance between different treatments. *and** represented significance at 0.05 and 0.01 probability level, "NS" means difference is not significant. The same below.

It was shown that the grain weight per panicle of F2M1 treatment was higher, indicating that under this cultivation condition, plant ontogeny was better, and source-sink was coordinated, which was conducive for the growth and development of plant monomers (Table 4). The 1000-grain weight, panicle weight and grain weight per panicle were higher in F5M1 treatment. The results showed that the cultivation conditions of low density and high fertilizer were beneficial for the accumulation of dry matter per plant, while the final population yield decreased because of the low density. However, under the condition of high density, 1000-grain weight, panicle length, grain weight per panicle and panicle weight were limited, and the competition for nutrients among plants was fierce. The nutrient supply of F5 treatment was sufficient and the population yield was higher. Under this cultivation condition, the effect of monomer effect on yield was less than that of population effect, and finally led high yield.

Table 4. Joint effects of two factors on yield and related characters.

\begin{tabular}{cccccc}
\hline $\begin{array}{c}\text { Experimental } \\
\text { Factor }\end{array}$ & $\begin{array}{c}\text { Thousand } \\
\text { kernel } \\
\text { weight } \mathbf{( g )}\end{array}$ & $\begin{array}{c}\text { Panicle } \\
\text { length } \\
\mathbf{( c m )}\end{array}$ & $\begin{array}{c}\text { Grain weight } \\
\mathbf{( g )}\end{array}$ & $\begin{array}{c}\text { Spike } \\
\text { weight } \\
\mathbf{( g )}\end{array}$ & $\begin{array}{c}\text { Grain } \\
\text { yield } \\
\left(\mathbf{k g} / \mathbf{h m} \mathbf{m}^{\mathbf{2}}\right.\end{array}$ \\
\hline F1M1 & $24.73 \mathrm{ab}$ & $23.73 \mathrm{a}$ & $81.98 \mathrm{abc}$ & $104.15 \mathrm{bc}$ & $7895.11 \mathrm{~g}$ \\
\hline F1M2 & $22.04 \mathrm{~b}$ & $22.66 \mathrm{ab}$ & $69.50 \mathrm{bcd}$ & $89.50 \mathrm{bcd}$ & $8818.44 \mathrm{defg}$ \\
\hline F1M3 & $22.66 \mathrm{~b}$ & $22.47 \mathrm{ab}$ & $70.53 \mathrm{bcd}$ & $89.19 \mathrm{bcd}$ & $9301.14 \mathrm{cde}$ \\
\hline F1M4 & $22.23 \mathrm{~b}$ & $21.88 \mathrm{~b}$ & $65.72 \mathrm{~d}$ & $79.45 \mathrm{~d}$ & $8966.17 \mathrm{defg}$ \\
\hline
\end{tabular}




\begin{tabular}{cccccc}
\hline F2M1 & $24.78 \mathrm{ab}$ & $22.94 \mathrm{ab}$ & $86.25 \mathrm{a}$ & $106.79 \mathrm{ab}$ & $8076.17 \mathrm{fg}$ \\
\hline F2M2 & $24.84 \mathrm{ab}$ & $21.30 \mathrm{~b}$ & $71.85 \mathrm{abcd}$ & $88.71 \mathrm{bcd}$ & $7902.74 \mathrm{~g}$ \\
\hline F2M3 & $25.05 \mathrm{ab}$ & $21.96 \mathrm{ab}$ & $74.40 \mathrm{abcd}$ & $90.58 \mathrm{bcd}$ & $9489.83 \mathrm{cde}$ \\
\hline F2M4 & $24.21 \mathrm{~b}$ & $21.76 \mathrm{~b}$ & $66.25 \mathrm{~d}$ & $92.57 \mathrm{bcd}$ & $9865.11 \mathrm{bcd}$ \\
\hline F3M1 & $24.61 \mathrm{~b}$ & $22.30 \mathrm{ab}$ & $79.96 \mathrm{abcd}$ & $103.31 \mathrm{bc}$ & $8991.51 \mathrm{defg}$ \\
\hline F3M2 & $25.04 \mathrm{ab}$ & $22.24 \mathrm{ab}$ & $76.79 \mathrm{abcd}$ & $97.89 \mathrm{bcd}$ & $9165.85 \mathrm{cdef}$ \\
\hline F3M3 & $23.51 \mathrm{~b}$ & $23.75 \mathrm{a}$ & $76.97 \mathrm{abcd}$ & $96.85 \mathrm{bcd}$ & $9457.19 \mathrm{cde}$ \\
\hline F3M4 & $23.99 \mathrm{~b}$ & $21.47 \mathrm{~b}$ & $74.39 \mathrm{abcd}$ & $84.69 \mathrm{~cd}$ & $9587.47 \mathrm{bcde}$ \\
\hline F4M1 & $23.68 \mathrm{~b}$ & $22.59 \mathrm{ab}$ & $80.46 \mathrm{abcd}$ & $107.09 \mathrm{ab}$ & $7875.04 \mathrm{~g}$ \\
\hline F4M2 & $23.71 \mathrm{~b}$ & $22.83 \mathrm{ab}$ & $73.07 \mathrm{abcd}$ & $92.56 \mathrm{bcd}$ & $8483.22 \mathrm{efg}$ \\
\hline F4M3 & $24.02 \mathrm{~b}$ & $22.50 \mathrm{ab}$ & $71.42 \mathrm{abcd}$ & $80.74 \mathrm{~d}$ & $10208.29 \mathrm{bc}$ \\
\hline F4M4 & $23.57 \mathrm{~b}$ & $21.84 \mathrm{~b}$ & $67.42 \mathrm{~cd}$ & $81.41 \mathrm{~d}$ & $10181.12 \mathrm{~b}$ \\
\hline F5M1 & $27.72 \mathrm{a}$ & $22.02 \mathrm{ab}$ & $83.35 \mathrm{ab}$ & $123.82 \mathrm{a}$ & $8025.66 \mathrm{fg}$ \\
\hline F5M2 & $23.27 \mathrm{~b}$ & $22.34 \mathrm{ab}$ & $71.57 \mathrm{abcd}$ & $84.76 \mathrm{~cd}$ & $8466.13 \mathrm{efg}$ \\
\hline F5M3 & $24.15 \mathrm{~b}$ & $21.68 \mathrm{~b}$ & $75.43 \mathrm{abcd}$ & $96.54 \mathrm{bcd}$ & $9413.37 \mathrm{cde}$ \\
\hline F5M4 & $25.16 \mathrm{ab}$ & $21.92 \mathrm{ab}$ & $76.60 \mathrm{abcd}$ & $90.72 \mathrm{bcd}$ & $11701.97 \mathrm{a}$ \\
\hline
\end{tabular}

\subsection{Effects of Fertilizer Application rate and density on yield and related characters of Sorghum}

The results showed that the yield of sorghum at high density $\left(128000\right.$ plants $/ \mathrm{hm}^{2}, 154000$ plants $/ \mathrm{hm}^{2}$ ) was significantly higher than that at low density $\left(96000 \mathrm{plants} / \mathrm{hm}^{2}, 109000 \mathrm{plants} / \mathrm{hm}^{2}\right)$, and reached the maximum at the density of $15.4 \mathrm{~kg} / \mathrm{hm}^{2}$. The 1000 -grain weight, panicle length, grain weight per panicle and panicle weight decreased with the increase of density, which was consistent with the results of Wang [14]. When the effect of single plant on grain yield of sorghum exceeded that of population, the total yield of population decreased. This shows that reasonable and appropriate increase of density is an indispensable important measure to increase the yield of density-tolerant sorghum varieties, and the cultivation of high density is an important technical measure for obtaining high yield of sorghum. Although the amount of fertilizer application were the same, different fertilizer ratio still affected the formation of yield. Under the cultivation with high density, the yield increased with the increase of fertilizer amount or the proportion of potassium fertilizer. This is similar to the results of previous studies on maize. Wu also thinks that potassium fertilizer can increase the yield of maize significantly [15]. Yin believes that potassium affects the yield and quality of maize by affecting the normal development of maize roots, stems and leaves, the absorption of water and nutrients, and the synthesis and transport of photosynthates [16]. Chang also thinks that the effect of the appropriate amount of potassium fertilizer on yield was positive [17]. The yield of sorghum was better under high fertilizer application rate of $750 \mathrm{~kg} / \mathrm{hm}^{2}$ and benefited from 1000 -grain weight, indicating that adequate storage capacity is necessary for high yield of sorghum.

The formation of sorghum biological yield is mainly dependent on leaf photosynthesis. Therefore, by increasing leaf area index, plant photosynthesis efficiency and yield per plant can be improved, which is one of the important conditions for obtaining high yield of sorghum [18-19].

\subsection{Effects of Fertilizer amount and density on leaf area index of Sorghum}

In this study, leaf area index increased with the increase of planting density. There was no significant difference in leaf area index and yield under different fertilizer application rates with low density (96000 plants $/ \mathrm{hm}^{2}, 108000$ plants $\left./ \mathrm{hm}^{2}\right)$. Under high density conditions $\left(128000 \mathrm{plants} / \mathrm{hm}^{2}\right.$, 154000 plants $/ \mathrm{hm}^{2}$ ), leaf area index (LAI) of $750 \mathrm{~kg} / \mathrm{hm}^{2}$ fertilization application was higher than that of $375 \mathrm{~kg} / \mathrm{hm}^{2}$ fertilization application. Different fertilization ratios could change yield by adjusting leaf area index (LAI). The results of this study also showed that all fertilizer applications could achieve the requirements of normal plant growth and development. At high density, plants needed a large amount of nutrients and increased potassium fertilizer to ensure the normal growth of plant leaves, prolong the functional period, and improve leaf area index. Under the conditions of $750 \mathrm{~kg} / \mathrm{hm}^{2}(\mathrm{~N}: \mathrm{P}: \mathrm{K}=1: 0.7: 1.6)$ and the density of 154000 plants $/ \mathrm{hm}^{2}$, the leaf area index reached the maximum, which was similar to the results of Shen's study [20]. 


\subsection{Effects of Fertilizer amount and density on photosynthetic characteristics of Sorghum}

The results of this study showed that the photosynthetic of sorghum leaves was inhibited by high fertilizer application, especially in the late growth period of sorghum, the photosynthetic rate decreased with the increase of density. The main reason for low photosynthetic in the high-density population is that the plants was compact, the ventilation and light transmittance were poor, and the leaves were senescent rapidly in the late growth period, which led to the low photosynthetic per plant in the highdensity population. The photosynthetic rate of F5M1 was significantly higher than that of other treatments at the flowering stage and decreased rapidly at maturity stage, but the spike weight of this treatment was larger, indicating that the leaf had a shorter functional period and higher efficiency. At appropriate densities, reasonable fertilization could improve canopy structure in plants, increase leaf area per plant, regulate leaf senescence and death in later growth stages, prolong photosynthesis time, and improve light energy utilization.

\section{Conclusions}

Different fertilizer application had significant effects on the yield of sorghum. The yield increased with the increase of fertilizer application. Different density also had significant effect on grain sorghum yield. The density yield of $128000 \mathrm{plants} / \mathrm{hm}^{2}$ and $154000 \mathrm{plants} / \mathrm{hm}^{2}$ was significantly higher than that of $96000 \mathrm{plants} / \mathrm{hm}^{2}$ and $109000 \mathrm{plants} / \mathrm{hm}^{2}$. With the increase of density, 1000-grain weight, panicle length, grain weight per panicle and panicle weight decreased. The results showed that higher yield $\left(11701.97 \mathrm{~kg} / \mathrm{hm}^{2}\right)$ could be obtained under the condition of $750 \mathrm{~kg} / \mathrm{hm}^{2}(\mathrm{~N}: \mathrm{P}: \mathrm{K}=1: 0.7: 1.6)$ and density 154000 plants $/ \mathrm{hm}^{2}$. During the whole growth period, under the condition of the same amount of fertilizer application, the photosynthetic rate decreased with the increase of density. Under the condition of the same density, the content of chlorophyll increased with the increase of fertilizer application. Under the condition of the same amount of fertilizer application, the content of chlorophyll decreased with the increase of density. The leaf area index increased with the increase of population density.

Acknowledgement. This study is supported by the program of cultivation on campus of Heilongjiang Bayi Agricultural University (XZR2014-02), the training program of innovation and entrepreneurship for college students in Heilongjiang Province (201910223056), and the characteristic discipline construction project of miscellaneous grain production and processing in Heilongjiang Province, and Projects (QC2018023), (LBH-Z14041), (2015M581420), (31301769), (CVB2012-009).

\section{References}

1.ZHANG, Y. F., WANG, Y. F., LIU, L. X., HOU, X. Y., Research progress on arid-land agriculture in northern China. Geogr. Respaniclech., 3, 2002, 305-312.

2.LU, Q. S., SUN, Y., 2005. Hybrid sorghum genetic improvement. China. Agri. Sci. Technol. Press., 2005, 48-52.

3.ZHANG, Y., TONG, B., WU, X. Q., ZHANG, R. P., FU, L. S., ZHU, Z., Effects of Different Fertilizer Level and Planting Density on Yield and Quality of Soybean. Soybean Science, 1, 2010, 444447.

4.ZHANG, Y. J., SONG, Y. M., LI, C. P., WANG, T. F., LUO, J. F., WANG, S. S., Study on the Yield Effect of Different Fertilizer and Density Comb Ination for High Grade Wheat. J. Henan. Inst. Sci. Technol., 3, 2003, 11-12

5.GONG, H. J., DONG, Z. F., JI, C. Y., 2008. The Influence of Cultivation Density and Base Fertilizer Dosage on Rice Yield. J. Anhui. Agri. Sci., 18, 2008, 7602-7604.

6.HUANG, K. J., YANG, H. Q., TAN, H., WEI, G. N., Study on fertilizer applying amount and the best density for high yield autumn Maize cultivation techniques. J. Maize. Sci., 1, 2001, 57-59.

7.ZHANG, M. Z., Application of the Technique of Two Row with Big Ridge in Corn Cultivation. $J$. Anhui. Agri. Sci., 12, 2006, 2664-2696. 
8.LIU, Y. S., ZHAO, G. Q., The effects of different cultivation densities on the yield of wine sorghum in renhuai city, guizhou province. Beijing Agri., 9, 2013, 1-13.

9.JIA, D. H., WANG, Z. M., LIN, P., CHEN, Y. H., Effect of Various Amount of Fertilizer Planting and Densities on Yield and Sugar Content of New Sweet Sorghum 3. Xinjiang. Agri. Sci., 1, 2010, 47-53. 10.LV, Y. D., NIU, Z. W., LI, H. Y., GUO, X. H., LIU, L. H., TONG, B., ZHANG, Y. M., ZHENG, G. P., Influences of Different Fertilizer Quantity on Growth and Yield of Hybrid Sweet Sorghum. $J$. Heilongjiang. Bayi. Agri. Univ., 3, 2006, 17-20.

11.ZHANG, W. Q., FAN, Y. L., ZHANG, S., LU, B. S., DUAN, L. S., LI, Z. H., TAN, W. M., Waxy Maize Yield in Response to a Novel Plant Growth Regulator and Plant Density. Int. J. Agri. Biol., 2, 2019, 304-312.

12.DING, G. X., ZHAO, G. L., LIU, T. M., ZHANG, C. W., NI, X. L., CHEN, G. M., Effect of planting density on the growth and yield of sorghum guojiaohong. China Seed Ind., 2, 2010, 43.

13.SHARIFI, R. S., HAMLABAD, H. B., AZIMI, J., Plant population influence on the physiological indices of wheat (Triticum aestivum L.) cultivars. Int. Respaniclech. J. Plant. Sci., 5, 2011, 137-142.

14.WANG, Y., WANG, E. J., WANG, Y., YANG, L. G., Effects of Planting Density on Growth and Yield of an Edible Sorghum Hybrid 'Liaoza 13'. Liaoning. Agri. Sci., 6, 2010, 24-27.

15.WU, W., ZHANG, K., WANG, X. F., SUN, S. R., WANG, L. C., Effect of K Application for Increasing Yield and Income And Its Utilization Ratio on Corn. J. Maize. Sci., 1, 1998, 61-65.

16.YIN, C. X., XIE, J. G., HOU, Y. P., ZHANG, G. H., WANG, L. C., YU, L., DONG, B. C., Effect of Potassium on Growth, Development and Physiological Function of Maize. Jilin. Agri. Sci., 5, 2008, 24-25.

17.CHANG, Y., YAN, W. P., SUN, N., WU, C. S., HU, W. H., GU, Y., Effects of potassium fertilizer application rate on lodging resistance properties and yield of maize. Soil. Fertil. Sci. China., 5, 2014, 47-52.

18.LI, N., ZHAI, Z. X., LI, J. M., DUAN, L. S., LI, Z. H., Effect of sowing date and density on sink/source relationship and canopy light transmission of summer maize (Zea mays L.). Chine. J. EcoAgri., 5, 2010, 959-964.

19.LI, M., LI, W. X., Regulation of Fertilizer and Density on Sink and Source Traits and Yield of Maize. Sci. Agri. Sinica., 8, 2004, 1130-1137.

20.SHENG, J. H., JIANG, D., DAI, T. B., JING, Q., TIAN, Y. C., CAO, W. X., Effects of fertilizer levels on photosynthetic characteristics of flag leaf and contents of protein and yield in grain in specialty wheat. J. Nanjing. Agri. Univ., 1, 2003, 1-5.

Manuscript received: 1.06 .2020 